\title{
Transatlantica
}

Revue d'études américaines. American Studies Journal

\section{The CEO Art Museum Director: Business as Usual?}

Jennifer A. Donnelly

\section{(2) OpenEdition}

\section{Journals}

Édition électronique

URL : https://journals.openedition.org/transatlantica/5044

DOI : $10.4000 /$ transatlantica. 5044

ISSN : 1765-2766

Éditeur

Association française d'Etudes Américaines (AFEA)

Référence électronique

Jennifer A. Donnelly, «The CEO Art Museum Director: Business as Usual? », Transatlantica [En ligne], 2 | 2010, mis en ligne le 15 avril 2011, consulté le 31 janvier 2023. URL : http://

journals.openedition.org/transatlantica/5044; DOI : https://doi.org/10.4000/transatlantica.5044

Ce document a été généré automatiquement le 31 janvier 2023.

\section{(c) (i) (9)}

Creative Commons - Attribution - Pas d'Utilisation Commerciale - Pas de Modification 4.0 International - CC BY-NC-ND 4.0

https://creativecommons.org/licenses/by-nc-nd/4.0/ 


\title{
The CEO Art Museum Director: Business as Usual?
}

\author{
Jennifer A. Donnelly
}

During the dramatic growth of United States art museums over the last twenty years, many of their directors seem to have assumed the role of CEO. ${ }^{1}$ Certain leaders have migrated to museums from the fields of business or administration, or have been selected for their fundraising abilities. Some have conspicuously employed strategies for raising funds and widening museums' audiences that seem to resemble private enterprise.

2 These issues have incited heated debate among museum professionals, critics, and audiences. Management strategies associated with the private sector are often argued to be tertiary, even contradictory, to the status of museums as not-for-profit, essentially educational institutions whose fundamental purpose is to acquire, exhibit, and interpret works of art. ${ }^{2}$ This argument often accompanies an assumption that a rupture has occurred with the way museums have traditionally been run. As the outgoing director of the Henry Art Gallery at the University of Washington, Richard Andrews, commented in early 2008: "Gone is the time that you could think about art all day and head a museum."3

3 But did such a time ever truly exist? The business-arts relationship has been central since the inception of museums in the United States; the roots of American art museums and collections are in private wealth and business, particularly in fortunes built through finance and industry, as opposed to Europe's system of royal and state patronage. American museums have arguably never observed a strict separation between the interests of "business" and those of "art", and museum directors have always needed to cultivate certain relationships with the private sector.

4 Much contemporary analysis of the profession does not sufficiently emphasize this historically central relationship. This paper, therefore, attempts to place contemporary trends in museum leadership in historical context as a means of understanding the significance of this legacy for today's museum leaders. The first part examines art museum directors and presidents over the past decade, in order to assess the current 
state of affairs. The second part reviews the historical evolution in training, experience, and practices of American museum directors since the establishment of the first major museums beginning in the 1870s, seeking shifts in the balance between art historical knowledge and business savvy. This comparison seeks to establish the extent of CEOstyle museum management, identify its longer-term historical origins, and point towards an assessment of its consequences for the museum's mission: does the possession of "business" skills by a museum director truly risk compromising the museum's mission, or are they essential for the survival of the institution in today's leisure-time landscape, which is glutted with alternatives for education, entertainment, and outlets for viewing art?

\section{Art Museum Directors in the 21 st Century: Scholars or CEOs?}

5 In any museum, a dichotomy exists between responsibilities directly relating to the objects in the collection and those dealing with the business of managing an institution. "Art" activities include curating exhibitions, education and outreach, research, and conservation. "Business" tasks include overseeing contract management, policy development, budget planning, financial control, fundraising and grant development, and income-producing activities such as concessions, fees, and retail. ${ }^{4}$ This dichotomy is particularly significant in museums that are privately managed and (for the most part) funded. Since the 1990s, the job titles of many museum directors formally reflect their status as CEOs. In 1997, the Philadelphia Museum of Art added CEO to Anne d'Harnoncourt's title of Director, which she had held since 1982; in 1999, the Metropolitan Museum of Art did the same for Philippe de Montebello, who had been Director since $1978 .{ }^{6}$ The number of directors with this title was so numerous by the end of the 1990s that the Association of American Museums was organizing roundtables for CEOs/Directors at its annual conference. Titles alone, however, do not define job descriptions or describe the individuals in these positions; the following three criteria give a clearer sense of the profiles of today's museum directors: educational training, professional experience, and practice.

\section{Education and Experience: The Art Historian}

6 Amongst current directors of major United States museums, educational backgrounds are almost unanimously in art history, at the level of $\mathrm{PhD}$ or another advanced degree in the field, and professional experience is in museum and gallery work, as the following table shows:

Fig. 1: Educational Backgrounds of Directors of Ten Major Art Museums, U.S., 20087

\begin{tabular}{|l|l|l|}
\hline Museum & Director & $\begin{array}{l}\text { Education* } \\
\text { (all degrees in Art History, unless noted) }\end{array}$ \\
\hline \hline Art Institute of Chicago & James Cuno & PhD Harvard \\
\hline
\end{tabular}




\begin{tabular}{|c|c|c|}
\hline Dallas Museum of Art & John Lane ${ }^{8}$ & $\begin{array}{l}\text { BA Williams College } \\
\text { MBA University of Chicago } \\
\text { MA, PhD Harvard }\end{array}$ \\
\hline High Museum of Art, Atlanta & Michael Shapiro & $\begin{array}{l}\text { BA Hamilton College } \\
\text { MA, PhD Harvard } \\
\text { MA, Williams College }\end{array}$ \\
\hline $\begin{array}{l}\text { Los Angeles County Museum } \\
\text { of Art }\end{array}$ & Michael Govan & $\begin{array}{l}\text { BA Williams College } \\
\text { UC San Diego (graduate work) }\end{array}$ \\
\hline Metropolitan Museum of Art & $\begin{array}{l}\text { Philippe de } \\
\text { Montebello }\end{array}$ & $\begin{array}{l}\text { BA Harvard } \\
\text { BA, MA Institute of Fine Arts at New York } \\
\text { University }\end{array}$ \\
\hline Museum of Fine Arts, Boston & Malcolm Rogers & BA, PhD Oxford (in English) \\
\hline Museum of Fine Arts, Houston & Peter C. Marzio & $\begin{array}{l}\text { MA Juniata College } \\
\text { MA, PhD University of Chicago }\end{array}$ \\
\hline $\begin{array}{l}\text { Museum of Modern Art } \\
\text { (MoMA) }\end{array}$ & Glenn D. Lowry & $\begin{array}{l}\text { BA Williams College } \\
\text { PhD Harvard }\end{array}$ \\
\hline National Gallery of Art & Earl A. Powell III & $\begin{array}{l}\text { BA Williams College } \\
\text { MA, Ph.D. Harvard }\end{array}$ \\
\hline Philadelphia Museum of Art & Anne d'Harnoncourt & $\begin{array}{l}\text { BA Radcliffe College (Harvard) } \\
\text { MA Courtauld Institute of Art }\end{array}$ \\
\hline
\end{tabular}

7 The professional experience of these directors is too extensive to list here; in short, all have previously worked as curators, were directors of other museums, taught at university level, or a combination of all of these. For example, de Montebello had been curator at the Metropolitan and director at the Houston Museum of Art; Lowry had been a researcher, curator, and then director at the Art Gallery of Ontario; Cuno directed the Harvard University Art Museums and the Courtauld Institute of Art in London. Even Thomas Krens, the director of the Guggenheim museums from 1988 to 2005 whose Masters in Business Administration (MBA) and strategies of global expansion and brand-building earned him epithets such as "The CEO of Culture Inc", ${ }^{10}$ holds an MA in Art History (as well as a BA from, again, Williams College) and taught the subject at the college level for 17 years.

While art museum directors have generally been educated as art historians, a few recent examples can be cited of directors without education or work experience in the arts and museums. For example, Andrea Rich, before directing the Los Angeles County Museum of Art (LACMA) from 1995 to $2005,{ }^{11}$ served the administrative position of Vice-Chancellor and Chief Operating Officer of the University of California at Los Angeles. The founding Director of the Smithsonian National Museum of the American Indian, W. Richard West Jr., had worked as an attorney in private practice before 
joining the museum in 1989 (he retired in 2007). These examples are the exception, however, not the rule.

\section{Policies and Practices: The CEO}

Professional activities prove more resistant to categorization than education and work experience. The work directly related to the objects of art-the presentation of the collection, organization of exhibitions, preparation of catalogues and other publications-is the responsibility not of directors, but of curators (whose backgrounds are nearly always in Art History or in the relevant field of scholarship.) In a 1981 study on the professionalization of the museum field, sociologist Vera Zolberg described the behavior of "bureaucratic managers" as follows: "eschewing aesthetic expertise, they try to run museums as rationally as they claim modern firms function: introducing methods of membership development (including advertisement), gaining control of local patronage markets, and lobbying for and trying to monopolize governmental funding sources." ${ }^{12}$ Today, the job description of nearly every museum director includes these tasks to a certain degree. Such responsibilities stand regardless of the director's educational background. For example, the MoMA's director, Glenn Lowry, has a doctorate from Harvard and an expertise in Islamic art; but a primary consideration for his appointment was his "rare combination of scholarly distinction and entrepreneurial savvy," as demonstrated by his fundraising success at the Ontario Art Gallery. ${ }^{13}$ His most noticeable achievement at the MoMA has been overseeing the $\$ 858$ million building expansion completed in 2004 .

The directness of interaction with the works in a museum's collection can vary according to the institution and to the individual at its head. Chicago's James Cuno continues to make presentations at scholarly conferences and to publish original work. At the large and well-endowed Metropolitan, the President receives a salary, ensuring a full-time paid employee to oversee organizational and financial strategy while allowing the director to concentrate on artistic and educational vision. However, most museums cannot afford this luxury, particularly smaller to mid-sized museums, and most directors are closely involved with duties such as negotiations, donor relations, or trustee relationships. A museum director must be "P.T. Barnum with a PhD" in the words of Franklin W. Robinson, director of Cornell University's art gallery. ${ }^{14}$

11 What is taking place is not a wholesale replacement of scholars with businessmen, but rather a reconfiguring of responsibilities that include art historical knowledge as well as financial and practical know-how. In short, most museum directors have training in art history and museum work, but their responsibilities include management, fundraising, administration, and overseeing building construction or expansion, whether through formal education or on-the-job experience. How was this labor divided in earlier historical periods?

\section{The Evolution of a Profession}

\section{Impresarios and Industrialists: 1870-1910}

12 The first large-scale, encyclopedic museums in the United States were founded following the Civil War in the wave of industrialization, urbanization, and territorial 
expansion. In the year 1870 alone, charters were given to the Metropolitan Museum of Art, the Museum of Fine Arts in Boston, and the Corcoran Gallery of Art; these were rapidly followed by museum openings in Chicago (1872), Philadelphia (1877), Detroit (1885), and Cincinnati (1886), among others. From 1900 to 1919, nineteen additional museums were established. The task facing early museum directors was literally to build the institutions from the ground up: construct galleries, assemble collections, hire staff.

Meeting such needs required the ability to muster material support as much as, if not more so, than expertise on some field of visual arts. While several museums received some token of public support-for example, the grounds for the Metropolitan were provided by the city of New York-the primary sources of financing and collections were private. At the Metropolitan, the contributions of early presidents and benefactors such as railroad executive John Taylor Johnston and financier J.P. Morgan formed the institution's cornerstones. The fortune of banker William Wilson Corcoran funded his eponymous museum. These early patrons, the so-called "Robber Barons," had made fortunes in industry. The profits from oil, railroads, sugar, steel, and trade became transformed into paintings, sculptures, tapestries, vases, and decorative arts. Industrialists, or "businessmen," became collectors, and the collections became the seeds of the new museums. Morgan even notoriously succeeded in influencing new legislation on import duties, which facilitated his bringing his collection into the country but ultimately benefited the Metropolitan: much of his collection went on display there, and was eventually donated to its permanent collection.

The civic groups active in creating these early museums included figures from the arts as well as from business; the founding group of the Metropolitan, for example, included poet William Cullen Bryant and artists Frederic E. Church (himself privately wealthy), Eastman Johnson, \& John Frederick Kensett. Nonetheless, the financial and political contributions of business were indispensable to the acquisition of works and construction of galleries.

In this initial phase of growth in museums, described by Zolberg as "pre-professional," the backgrounds of directors varied. Sociologist Richard Peterson identifies them as "impresarios" whose "colorful histories had nothing to do with the arts." 15 Zolberg writes of "relatively inexperienced amateurs" for whom "pleasant demeanor, social connections through family ties, graceful but unspecialized taste were of greater importance than formally acquired competence." ${ }^{16}$ One factor in this lack of coherency is due in part to the newness of the museum institution. The parameters of the various jobs and roles, having no precedent, were not yet fixed. A second factor is the state of art history at the time; the field was not yet highly developed as a formal discipline of study in the United States. When the first encyclopedic museums were being established, only a few universities had courses in the subject. Lectures in art were offered at Harvard beginning in 1874 by Charles Eliot Norton and in the early 1880s at Princeton (then called the College of New Jersey) and at women's colleges such as Vassar, Bryn Mawr, Radcliffe, Smith, and Wellesley. ${ }^{17}$ Early departments were closely linked with Classics and Archaeology, which was just beginning to be developed as a scientific field. Several decades passed before these departments began to solidify and their alumni to gain leadership positions in museums.

Moreover, the nature of early museum directors' tasks did not entirely demand an extensive degree of scholarship. Peterson claims that the "impresario" directors 
"devoted most of their time to cultivating relationships with administrators and with other museum patrons."18 One such "impresario" was the first director of the Metropolitan Museum of Art, General Luigi Palma di Cesnola (from 1879 to 1904). Cesnola, who was born in Italy, immigrated to the United States in 1860; he had served in the American Civil War; through the political connections established in this position, he was appointed American Consul in Cyprus in 1865. This location introduced Cesnola to the nascent discipline of archaeology and he became involved in the excavations underway at that time, amassing a large collection of Cyprian sculpture and other antiquities through this work and through purchases. The collection was ultimately acquired by the Metropolitan Museum, funded in large part by private donations and subscriptions. ${ }^{19}$ Following this acquisition, Cesnola was named to the museum's board in 1877 and as its first director in 1879. In Boston, the Museum of Fine Arts was headed by another "pre-professional" curator and then director, Charles Greely Loring, from 1881 to 1902. Member of a blueblood Bostonian family and general in the U.S. army, Loring's legacy was overseeing two building expansions and acquiring a number of donations for the museum's collection.

While such patrons were collectors, they were not necessarily scholars; as Alan Wallach has pointed out, they were accused by contemporaries of knowing "more about pork barrels and molasses than [...] about art." ${ }^{20}$ Questions as to the relative sophistication and motivations of the early benefactors notwithstanding, their contributions during this first stage of American museum development were essential. Their prominence does not imply that money was valued more than art, or that museums blossomed entirely due to business, but simply that private wealth and businessmen played a crucial part in getting them built; therefore the role of the first museum directors was necessarily wrapped up in this symbiosis between arts and business. For directors, erudition and scholarship were less important than social connections and savoir-faire owing to the job requirements as well as to limited access to specialized education.

\section{“Collectors, Art Historians, and Modern Managers": 1910-1966}

As the art museum matured as an institution and art history developed as an academic discipline in the United States, the training of art museum directors became more specific. In 1912, the extent of art history instruction at the university level in the United States was surveyed by Princeton professor Allan Marquand (son of banker and Metropolitan trustee Henry Gurdon Marquand), a Latin scholar who began teaching in the newly created art department in 1883. 420 courses were found, with 99 sub-fields. ${ }^{21}$ By the 1910s and 1920s, a number of art museum directors held university degrees in Art History, Archaeology, and Architecture from the solidifying academic departments. During this period, according to Zolberg's model, "amateurism was becoming unfashionable." 22

The beginning of a shift toward the professionalization of museum directorship can be seen in the changing of the guard at the Metropolitan in 1910. Cesnola, the museum's first director, was in Zolberg's terminology an "amateur" in archaeology, whereas its third, Edward Robinson, was a formally trained scholar in the field. The immediate successor of Cesnola, Sir Caspur Purdon Clark, had previously worked at England's South Kensington Museum (now the Victoria and Albert), an example for many American museums. The Metropolitan's selection of a director experienced in museum 
work already showed initial movement from the dilettantish figure of the impresario; this became pronounced with the appointment of the erudite Robinson. The Metropolitan's director from 1910 until his death in 1931, Robinson had studied archeology at Harvard (PhD 1879) and then in Berlin, made research trips to Greece, and lectured in the subject at Harvard (1893-94, 1898-02). He had previously worked as curator (1895-1902) and then director (1902-1905) at the Boston Museum of Fine Arts.

While the developing academic departments in art history trained museum directors with more systematic knowledge of art than previously, the tasks involved in running the museums still required close relationships with business. The construction of new museums and the expansion of pre-existing ones continued to proceed rapidly; between 1920 and 1939, twenty-seven new museums were built, among them the first modern art museums: the Whitney Museum of American Art, the Museum of Modern Art (both 1929), and the "Museum for Non-Objective Painting" (1939), founded, respectively, by heiress Gertrude Vanderbilt Whitney, three wives of wealthy industrialists (Lily Bliss, Abby Aldrich Rockefeller, and Marie Quinn Sullivan), and banker Solomon R. Guggenheim. Also during these years, businessmen, industrialists, and heirs built collections that would eventually be bequeathed to museums or become museums in their own right (Albert Barnes, Henry Clay Frick, Albert Gallatin, Isabella Stuart Gardner). As in the previous era, the construction of new buildings and wings and the acquisition of works and collections necessitated fundraising and building donor relationships. John Walker, first chief curator of the National Gallery of Art (founded 1937) and its director from 1956 to 1969, observed that the growth of museums "relies on gifts. These involve social relations. The director of a that large institution must know how to entertain with charm and sophistication." ${ }^{23}$

During this period, two distinct tasks emerged for museum directors: on the one hand, scholarship; on the other, fundraising and donor relationships. Museum professionals during this period exhibited art historical knowledge about objects as well as business knowledge about effectively managing the institution. In 1922 Harvard University began to offer the first course of instruction specifically designed to train future museum professionals. "Museum Work and Museum Problems," or simply "The Museum Course," was taught by Paul J. Sachs, an art collector and member of one of the banking families behind Goldman-Sachs. Sachs wrote that the ideal curator had "the passion of a collector, the preparation of an art historian, and the public service values and management practices of a modern manager." ${ }^{24}$ The approach emphasized connoisseurship and scholarship as well as strategic relationships with potential donors and other patrons.

The type of connoisseurship nurtured by Sachs' method did not consist simply in knowledge of names, dates, schools, provenance, although students were expected to display rote mastery of a wide range of historical schools and facts, as attested in the writings and memoirs of various alumni. ${ }^{25}$ Less quantitatively, future museum professionals were encouraged to develop an intimacy with works of art and to observe a certain "reverence for the object." ${ }^{26}$ Students handled objects in settings more approximating a collector's drawing room (classes often met in Sachs' own home) than a classroom.

23 Students were also furnished with contact names from a network of collectors and patrons, dealers, and other figures in the art world. Many of the students were themselves born to wealth; in any event, during this period the direction of art 
museums was essentially held by a specifically trained elite. Sachs' influence on museums was widespread; of his 388 students, 160 went on to assume top positions at American museums. ${ }^{27}$ Former student Edward Warburg (1930), later a member of the Metropolitan board, summed it up by saying that Sachs was "at that time the major force in training the museum directors and curators of this country, and in pulling together the necessary trustees to support and back their programs." ${ }^{28}$

The first director of the Museum of Modern Art, Alfred H. Barr, exemplified this ideal. Barr did the work of a curator: he designed the exhibition calendar, led research and publication projects (including the pamphlet Art in America), wrote catalogue text, promoted education programs, delivered radio addresses, and continued to teach at Wellesley College during his first years as director. His work was tireless and "passionate," to use Sachs' term. At the same time, he tapped into the impressive network of artists, critics, and others figures in the art world that he had built via student travels equipped with letters of introduction from Sachs to organize exhibitions and to acquire works that progressively became the heart of the museum collection. ${ }^{29}$

Sachs' student John Walker (cited above) writes in his memoir, tellingly titled Self Portrait with Donors, of his career-long quest to negotiate bequests from collectors whose fortunes came almost entirely from business concerns-oil tycoon Armand Hammer, stockbroker Chester Dale, retail chain owner Samuel Kress, Lessing J. Rosenwald of Sears Roebuck, Joseph E. Widener, heir to the fortune of his entrepreneur father, and the descendents of Gallery founder, industrialist Andrew Mellon. Slightly earlier, Edward Robinson had been active in securing for the Metropolitan the collections of department store baron Benjamin Altman in 1914 and "Sugar King" H.O. Havemeyer and his collector wife Louisine in 1929, as well as J.P. Morgan's collection after his death. Despite this facility with the "business" responsibility of donor relations, Walker went on to author two monographs in retirement; Robinson remained curator of antiquities for much of his directorship.

Museum directors coming from programs other than Sachs' similarly blended the traits of scholar, manager, and connoisseur. Fiske Kimball, Director of the Philadelphia Museum of Art from 1925 to 1955, had studied architecture at Harvard and the University of Michigan, taught Architecture and Art at the university level, ${ }^{30}$ and worked on the restoration of several historical homes, including those of Thomas Jefferson and Robert E. Lee's family. Throughout his museum career, he continued to publish scholarly books. ${ }^{31}$ At the same time, his projects at the Philadelphia Museum of Art involved considerable savvy in business and management, notably raising funds and overseeing construction of the new building after the 1929 stock market crash and the acquisition of the Arensberg and Gallatin collections.

Curator and director William T. Valentiner also combined a rigorous scholarly background with an impressive career in museum management. Born and educated in Germany, Valentiner was formative in the development of several U.S. museums: Curator at the Metropolitan Department of Decorative Arts (1908-1914), Director of the Detroit Institute of Arts (1924-1945) and of the LACMA's forerunner, the Los Angeles Museum of History, Science, and Art ${ }^{32}$ (1946-1958). In Berlin he had worked under Wilhelm von Bode, director of the Berlin Museums and arguably their "impresario". According to Valentiner, von Bode put his curators "through a museum training course of almost Spartan character," with stringent expectations regarding publication and 
erudition. ${ }^{33}$ In regards to the arts / business relationship, Valentiner's mentor, though a scholar with hundreds of publications to his name as well as a devoted connoisseur, had been formally educated not in art but in law. This training no doubt aided his negotiations for the large number of works he was responsible for acquiring.

The blend of competencies is particularly apparent in the example of Francis Henry Taylor, director of the Metropolitan from 1939 until 1954. A profile published in Time magazine in 1952 colorfully evokes his approach: "It takes a peculiar combination of scholar, executive and showman to run a venture like the Metropolitan. Francis Taylor seems to have the combination. Says a friend: 'He has the administrative ability of Eisenhower and the scheming patience of Machiavelli, and he bears a striking resemblance to Rodin's bust of Louis XVI.' Moreover, and more important, he can work in harness with such diverse types as learned curators and unlearned but connoisseur trustees. ${ }^{\prime 34}$ Taylor's background was strong academically and professionally: he had studied at the University of Pennsylvania, the Sorbonne, and Princeton and worked as curator at the Philadelphia Museum of Art and director of the Worcester Museum of Art (1931-1939). At the same time, he was an early proponent of temporary exhibitions, which have since become a major strategy for boosting attendance. At the time of the 1952 profile, seven temporary exhibitions were on display.

In short, directors during this period were systematically trained in scholarship, connoisseurship, and donor relations. Regarding donors, it must be noted that, while benefactors from the business world made extraordinary gifts during this period, the Depression and the New Deal also fashioned the federal government into patron. For museums one of the most significant programs was the Federal Art Project that ran from 1935 to 1943.President Roosevelt spoke on public radio at the inauguration of the MoMA's new building in 1939, lauding the value of museums to a democratic society: "In encouraging the creation and enjoyment of beautiful things we are furthering democracy itself. That is why this museum is a citadel of civilization." ${ }^{35}$ While such engagement was an integral thread in the cultural fabric of the times, the next generation of museum directors would find more reliable patronage from private corporations than from the government.

\section{From Connoisseurs to CEOs: 1966 and after}

30 In the late 1960s, the museum directors trained to embody Sachs' philosophy of connoisseurship, scholarship, and effective management began to give way to a new generation. In 1966, the directorship of the Metropolitan passed from James Rorimer, a graduate of Sachs' Museum Course, to Thomas Hoving, who in 1976 declared: "My job here is chief executive officer of an extremely large firm, one over which I have total supervision in all aspects." ${ }^{36}$ Two years later, in 1968, Harvard stopped offering the Museum Course. In 1969, the directorship of the National Gallery of Art was passed from Walker, a former student of Sachs and protégé of Bernard Berenson, to John Carter Brown, the first museum director to hold a Masters in Business Administration (Harvard, 1958). ${ }^{37}$ Around the same time, university programs for non-profit management appeared; in 1966 the first doctoral programs in arts administration were introduced at Yale and the University of Florida. In 1972 there were twelve such programs; by 1981 there were twenty-four. ${ }^{38}$ The curricula broadened the scope of expertise envisioned by Sachs, covering public policy, management, arts education, board relations, marketing, negotiating, fundraising, and development. While no major 
museum director of this era attended these programs, their growth indicates fresh emphasis on these tasks and a more methodical approach to supervising them.

In 1966, Walker defined the director's role as "mak[ing] sure the institution is effectively managed and then to raise funds to get acquisitions and balance his budget." ${ }^{39}$ In terms of the balance between art and business, the responsibilities of the new generation did not substantially depart from those of their predecessors. Financial support continued to be a significant issue for museums. While federal and regional government emerged as sources of funding-in 1965 the National Endowment for the Arts was founded, and between 1966 and 1983 its endowment grew from \$1.8 to \$131 million-growing inflation in the 1970s took its toll on museums' bank accounts. Directors continued to be responsible for seeking donations and raising funds, and the strategies employed to meet financial needs metamorphosed. New techniques were developed to broaden audiences; donors were sought not only among wealthy individuals, but among corporations; marketing gained importance.

The tenure of Thomas Hoving at the Metropolitan illustrates many changes that would define museums during this period and lead directly to the issues facing them presently. While Hoving's education was in art history (PhD Princeton, 1959) and he had experience in museum work (heading the Cloisters, operated as a department of the Met), ${ }^{40}$ as director he was known not for his erudition but for his aggressive policies of outreach and expansion. In his history of the Metropolitan, Calvin Tompkins described Hoving as a "master publicist", and argues that his image became closely associated with the museum, as a CEO's is with a company. ${ }^{41}$ By deaccessioning works from the permanent collection, which is explicitly discouraged by museums' mission statements, professional directives and usually by donors' wills, Hoving provoked controversy, but succeeded in raising funds for other more spectacular acquisitions (including the famed Euphronios krater, returned to Italy in 2008 following controversy over trafficking in illegal antiquities).

Hoving became associated with certain techniques for widening audiences, in particular the "blockbuster", the big-budget traveling exhibitions designed to attract mass audiences. The first such show in the United States is usually said to be "Treasures of Tutankhamen", shown at six museums (including the Metropolitan) between 1976 and $1978^{42}$ following its spectacular success at the British Museum in 1972. The Metropolitan was already organizing temporary exhibitions in the 1940s, as mentioned above; historian Francis Haskell cites much earlier institutional precedents-the 1913 Armory Show in New York City, the Salons in Paris, and even $17^{\text {th }}$-century exhibitions by the Académie royale de peinture et de sculpture. ${ }^{43}$ What has differentiated temporary traveling exhibitions after "Tutankhamen" has been the large scale and cost, the cooperation of multiple museum institutions, private collectors, even foreign governments and entertainment companies, and the web of related offerings (tie-in merchandise, marketing campaigns, tourism packages, corporate sponsorship). Hoving, a self-described CEO, and Brown, a diploma-holding MBA, were instrumental in bringing this first blockbuster to the United States. The latter's efforts in this regard even garnered a mention at his funeral by Senator Hillary Rodham Clinton: "The blockbuster transports us, opens our minds, hearts and imaginations with a wonderful experience we would talk about the rest of our days." ${ }_{44}$ flipside of creating the expectation that exhibitions should generate wide audiences 
and revenue. As a gross generalization, in this schema the inherent value of the works on display becomes subsidiary to their ability to attract visitors. Although from the perspective of university degrees, museum directors had not significantly changed, the commitment to connoisseurship-the "reverence for the object" -began to shift toward a less specialized engagement with art objects in an effort to reach continually wider and more diverse audiences. Noting the phenomenon of "bureaucratic managers" in 1981, Zolberg stated that "the expertise that they bring to bear on organizational functioning [was] becoming a necessity for efficient operations and justification of the public funds received." ${ }^{45}$ By the end of that decade, the need for this expertise was uncontested.

In the 1990s, general economic prosperity stimulated the growth of museums directly and indirectly. The rise of the U.S. stock market between 1993 and 2000 and the concurrent "irrational exuberance" encouraged extraordinary examples of sponsorship on private and corporate levels. Spectacular gifts were made by museum trustees: between 1993 and 2005, former Guggenheim chairman Peter Lewis, an insurance mogul, gave $\$ 77$ million of his personal wealth; in 2005, MoMA chairman emeritus David Rockefeller (descendent of the Standard Oil scion) pledged $\$ 100$ million to the museum, as well as several million more to the museums of Harvard (where he had been a student during Paul Sachs' tenure); real estate mogul Eli Broad funded a new building at the LACMA that opened in 2008; the Museum of Fine Arts of Houston was pledged $\$ 330$ million by Caroline Wiess Law, who passed away in 2003. Simultaneously, the rise in tourism, encouraged by this economic prosperity, and the transformation of the travel industry created booming audiences. The fall of the dollar and the faltering of the economy in the early years of the twenty-first century resulted in layoffs and cutbacks, but relatively little diminution in programs of expansion and traveling exhibitions.

\section{The Scholar / CEO Divide Today}

\section{Conflicts and Turnover}

The educational and professional background of current MoMA Director Glenn D. Lowry is not substantially different from that of Alfred H. Barr Jr. Both MoMA directors earned doctorates in Art History and worked in some capacity with the arts before heading the museum. A key difference is not so much the directors' profiles as the museum itself: when the Museum of Modern Art in New York was founded in 1929, the enterprise included a single director-curator, the scholarly Alfred H. Barr Jr., and three trustees, the wives of wealthy industrialists. Some eighty years later, there are chief curators in each of the museum's five departments and some 600 employees outside curatorial and management staff. Museums are now widely regarded, and rightly so, as crucial entities in the tourism industry as well as in education.

The blend of skills demanded of a director in this high-stakes, growth-focused environment is as rare as it is complex: a scholar's familiarity with the collections, a businessman's savvy with finances and negotiations, an administrator's ease with management. It is difficult to find candidates spanning these broad areas of competence, which is certainly a factor in the large number of museum directorships that have become vacant in the last few years. The rareness of this combination of skills 
is one factor in the high level of turnover at the top level of U.S. art museums in the beginning of the $21^{\text {st }}$ century; as of April 2008, eighteen of the nation's largest museums were seeking new directors. ${ }^{46}$

Another factor is that arts and business have difficulty cohabitating. Friction between the two realms has led to a number of personnel clashes as well as high-profile firings and resignations within the past few years. Certain clashes between arts and business personnel recur. While internal disagreement and "office politics" occur in any working environment, these examples arise specifically from conflicts between the objectives of "art" and of "business".

In one scenario, an executive museum position (other than the director's) is filled by an individual without training in art history or museum experience, but rather with a background in business or administration. For example, at the Smithsonian Institution, which comprises some eighteen museums of art and science, former Secretary Lawrence Small (2000-2007) had previously served as President of the federal mortgage banking agency Fannie Mae, following a 27-year career at Citibank. Barry Munitz, President and CEO of the J. Paul Getty Trust (which oversees the two Getty museums as well as the research foundation) from 1997 to 2006, had held high-ranking positions in university administration, as well as having worked ten years in the corporate world. Munitz also held a PhD and had some early teaching experience in literature and theatre, though not in the visual arts.

The practices of directors with business backgrounds drew criticism both internally and externally. Disagreements arose with more academically oriented curators and directors. For example, in 2002 the Director of the Freer and Sackler Galleries, museums in the Smithsonian network, led a petition calling for removal of Secretary Small. Critics copiously published condemnations of their behavior. A frequent target of venom was the influence exerted by individual and corporate sponsors, donors, and commercial entities. Small, for example, was widely criticized for becoming too close to the commercial realm with prominent corporate sponsorship, the prevalence of "naming opportunities" in galleries, and nearly allowing a donor to curate an exhibition. In the case of the Smithsonian, which receives federal funds, the Congress held hearings to examine possible grievances.

41 Another criticism of directors with business backgrounds relates to expenses. The Getty's Munitz, the Smithsonian's Small, and the Museum of the American Indian's West were all cited for lavish travel and living budgets-first-class airline tickets, luxury hotels, pricey meals, family members' travel-financed by the not-for-profit museums they worked for. Small was criticized by Senator Charles Grassley (R-Iowa) of the Senate Finance Committee for his "Dom Perignon lifestyle." ${ }^{47}$ West was accused by the same Senator of being "determined to meet Mr. Small's champagne lifestyle, glass for glass." ${ }^{48}$ These individuals defended their expenditures as part of the job of running organizations that are international, high-profile, and require entertaining and frequent travel-like a corporate executive in the private sector.

Such examples of spending behavior led to the business-style leader's removal. After years of pressure, Small resigned in 2007. Munitz was fired in 2006 and required to pay $\$ 250,000$ to the museum. West retired in 2008 , but spent his first months of retirement facing a drawn-out investigation of his past travel budgets in Congress and in the press. The LACMA's Rich resigned in 2005, in the midst of public disagreement with Trustee Eli Broad, who was funding an eponymous building, and following years of tensions 
with her staff, beginning with her arrogation of the title of Director in 1997 (previously she had been President and CEO).

In another scenario, the art specialists, not the business experts, quit their jobs or were pushed out due to the arts / business conflict. For example, Getty Director Deborah Gribbon quit her position in 2004 following repeated arguments with the abovementioned Munitz. ${ }^{49}$ Milo Beach of the Sackler and Freer resigned in protest of Lawrence Small's leadership tactics. Several directors with art historical education and backgrounds in museum work have resigned or been removed from their positions because their skills did not suit the museum's financial and business needs. At the Tampa Museum, the resignation of Emily Kass, who holds a Masters of Fine Arts, was requested so that her position could be given to a more experienced fundraiser. ${ }^{50} \mathrm{In}$ early 2005, two art historian directors left their positions as their museums announced major expansion projects (Katherine Reid of the Cleveland Art Museum and David Levy of the Corcoran Gallery of Art). While Reid officially cited retirement, it was speculated that this retirement was strongly encouraged by the board because she lacked the necessary fundraising and organizational skills.

Some art museum directors have left their jobs on the grounds of not liking the administrative and executive aspects of the job. At the DIA Art Foundation in New York, Jeffrey Weiss resigned from the directorship in early 2008 after less than a year on the job because, as he explained in an interview, the position "took me too far away from curatorial and scholarly work." 51 Ned Rifkin, the Smithsonian Institution's undersecretary for art, resigned in April 2008, commenting: "No one who loves art wants to be an administrator." ${ }^{52}$

\section{Commerce, Corporations, and Collections}

In addition to conflicts stemming from clashing objectives of arts and business, criticism has arisen for museum directors whose policies have been deemed inappropriately commercial. Tom Krens, while Director of the Guggenheim, gained particular notoriety in this respect. Under his direction, the museum accepted donations from companies whose products appeared in his exhibitions: BMW sponsored The Art of the Motorcyle (at the New York museum in 1997-1998), which included a number of its vehicles; the designer Giorgio Armani contributed a reported $\$ 15$ million at the time of the exhibition Giorgio Armani (2000-2001). Such practices raised questions of curatorial integrity. Krens expanded the museum as a global brand, opening a "branch" at the Venetian hotel and casino in Las Vegas, founding new museums in Berlin and Bilbao, and forging a partnership with the Hermitage in Russia. Ironically, Krens' policies of expansion were sufficiently aggressive to draw public criticism from the Chairman of the Board, Peter Lewis, himself a billionaire business mogul. Krens responded by mocking the source of the Chairman's wealth, retorting to a reporter: "Peter B. Lewis sells car insurance. I would not equate his views with mine." 53 Lewis ultimately resigned from this volunteer position in protest.

Along the same lines, Malcolm Rogers, Director of the Museum of Fine Arts, Boston (MFAB) since 1994, loaned artworks from the permanent collection to the Las Vegas hotel and casino Bellagio, which paid the museum a reported $\$ 1$ million dollars. The placement of pieces in a venue known not only for the morally dubious practice of gambling but also for rampant commercialism was widely criticized as a bid for income 
and publicity without any redeeming educational or curatorial value. Furthermore, under Rogers, the MFAB put on several exhibitions whose content had a direct link to commerce: fashion photography (Herb Ritts: Work, 1997-1998), a fashion designer's luxury cars (Speed, Style, and Beauty: Cars from the Ralph Lauren Collection, 2005), and guitars once owned by music celebrities such as Prince and John Lennon (Dangerous Curves: Art of the Guitar, 2000-2001). The treatment of commercial and popular culture themes by a number of museums has been criticized as pandering to audiences in order to boost attendance and therefore as elevating the concerns of business over art.

Similarly concerns are expressed over "blockbusters." The enthusiasm of Senator Clinton for the genre, expressed in her eulogy for the National Gallery's John Brown, is evidently shared by many museum visitors-such exhibitions regularly attract over a million visitors to a single venue-a good deal of museum professionals and critics are wary of them. ${ }^{54}$ Such exhibitions, they argue, siphon resources and attention from permanent collections and from worthy but possibly less sensational subjects; they distract from the museum's core missions of acquisition, preservation, and interpretation, and place the focus on attendance numbers, attention in the press, and growth for the museum.

\section{Business as Usual?}

The link between business and museums is evident in the profiles and policies of directors, as well as in the contents of the collections themselves. In a country without the tradition of royal, religious, or federal patronage the cornerstone of the first European museums, it has been private individuals, often businesspeople, who have stepped in to help fund buildings, donate artworks, and fill leadership positions as board members and presidents. U.S. museums still receive far less public funding than their counterparts abroad. As a result, American art museum directors have long had to maintain links with private business, in order to fulfill the fundamental objectives of acquiring, exhibiting, and interpreting works of art.

Despite this fundamental relationship between the arts and business, U.S. museums strive to downplay links with the commercial world, at least in mission statements and professional directives. At the same time, they rely on private business for their livelihood, and corporate sponsorship is deemed essential and is actively pursued. This creates an inherent tension for some that seems poised to define the next few decades of museum development. Rather than continue to pit commerce and art against each other, as though the two were diametrically opposed, it is probably more helpful to ask how they can serve each other to maximize the benefits to both.

Given the museum institution's increased complexity and diversified role, it is logical to require museum directors to share certain skills with executive officers. Museum directors are responsible for the health of their institutions, which includes financial and administrative aspects. Conversely, the work of a scholar demands a different set of skills than those required to run a large organization. It is logical to ask whether CEO-style management can appreciate the specialized knowledge necessary for curatorial work sufficiently to cede authority to the experts. It is also logical to ask whether scholarship and art history adequately prepare a director for the tasks of effectively managing and overseeing such a complex organism. 
51 In light of such questions, the Association of American Art Curators initiated a program in 2001 called the Center for Curatorial Leadership to train curators to become effective leaders in this landscape. Founder Elizabeth Easton explained that "what makes an art museum much different [from a business] is that art is at its core. It needs a director with scholarly distinction and a background in art who learns about management, as opposed to a manager who learns about art-a much more difficult proposition." ${ }^{55}$ Such programs provide a solution by which knowledge of and passion for art can be harnessed to leadership skills and realities of museum operations. Certainly, no museum director who wishes his museum to remain open should expect to sit back and "think about art all day," in the words of the outgoing director of the Henry Art Gallery. But neither can the museum's collection be perceived as another widget, a simple commodity to be managed and organized. The raison d'être of museums remains the diffusion of cultural and artistic knowledge, not growth or profit. In fulfilling their missions, American art museums have always relied upon scholars as well as businesspeople; defining the optimal division of labor will call for discussion and review as long as the museum institution continues to evolve.

\section{BIBLIOGRAPHIE}

ALEXANDER, Edward P., Museum Masters: Their Museums and Their Influence, Nashville, American Association for State and Local History, 1983.

ARROYO, Leah, “What They Really Want to Do is Direct." Museum News, Nov./Dec. 2007.

CUNO, James, ed. Whose Muse? Art Museums and the Public Trust, Princeton, Princeton University Press, 2004.

“Custodian of the Attic." Time, Dec. 29, 1952.

DONNELLY, Jennifer, GAUTIER, Mathilde, "Commerce, culture et mondialisation: les expositions événementielles aux États-Unis et en France." Patrimoine et mondialisation, Paris, L'Harmattan, 2008.

FEIGEN, Richard, Tales from the Art Crypt, New York, Random House, 2000.

“Glenn Lowry Presented with Distinguished Alumni Award.” www.holderness.org, Feb. 2005.

"Getty director steps down", Art in America, Dec. 2004

GRIMALDI, James V., "Portrait Cost Indian Museum $\$ 48,500$. Senators, Trustees Question Spending By Former Director.” Washington Post 4 Jan. 2008.

HACKETT, Regina, “Henry Gallery names director.” Seattle Post-Intelligencer 9 Jan.2008.

HASKELL, Francis, The Ephemeral Museum. Old Master Paintings and the Rise of the Art Exhibition, New Have, Yale University Press, 2000.

“J. Carter Brown Remembered for 'Blockbuster' Of a Life." OVATION, The Arts Network. 18 July 2002. 
KANTOR, Sybil G., Alfred H. Barr: The Intellectual Origins of the MoMA, Cambridge, MIT, 2002.

LEVINE, Faye, The Culture Barons: An Analysis of Power and Money in the Arts, New York: Thomas Crowell, 1976.

LOPEZ, Steve, “Munitz's Flight Plan Runs Into Head Wind.” LA Times, 31 Aug. 2005.

PETERSON, Richard A., "The Role of Formal Accountability in the Shift from Impresario to Arts Administrator." Sociologie de l'Art, Paris, La Documentation française, 1986.

PRUD'HOMME, Alex, “The CEO of Culture Inc.” Time. 20 Jan. 1992

ROBINSON, Franklin W., “P.T. Barnum with a PhD”, Museum News, March/April 2001.

SMYTH, Hugh, C., LUKEHEART, Peter M., eds.: The Early Years of Art History in the United States, Princeton University Department of Art and Archaeology, 1990.

SUDJIC, Deyan. "There's steel in his soul." The Guardian [London] 19 June 2005.

TASSEL, Janet. "Reverence for the object. Art museums in a changed world." Harvard Magazine, Sept-Oct. 2002, 48-58, 98-99; 49-50.

TOMPKINS, Calvin, Merchants and Masterpieces. The Story of the Met, New York, E.P. Dutton \& Co., Inc., 1970.

TRESCOTT, Jacqueline, "Smithsonian Undersecretary for Art Ned Rifkin to Leave in April." Washington Post: 13 March 2008.

--- \& James V. Grimaldi, “Smithsonian's Small Quits in Wake of Inquiry,” Washington Post: 27 March 2007.

VOGEL, Carol, “Director’s Brief Stay at Dia Is Over”, New York Times, March, 12008.

WALLACH, Alan, Exhibiting Contradictions: Essays on the Art Museum in the United States, Amherst, University of Massachusetts Press, 1998.

WALKER, John, Self-Portrait with Donors: Confessions of an Art Collector, Boston, Little, Brown, \& Co., 1969.

ZINK, Janet, “Tampa director faces a city's doubts.” St Petersburg Times, 13 Feb. 2005.

ZOLBERG, Vera, "Conflicting Visions in American Art Museums", Theory and Society, 10, 1981 : 103-25.

\section{NOTES}

1. Chief Executive Officer (Président de gestion).

2. The mission statements of individual museums, legal documents such as the Museum and Library Services Act, and the directives of organizations such as the American Association of Museums (AAM) and the International Council of Museums (ICOM), are consistent in this definition.

3. Cited in Regina Hackett. "Henry Gallery names director." Seattle Post-Intelligencer 9 Jan. 2008.

4. Specific competencies are outlined by the Association of Art Museum Directors (Professional Practices in Art Museums) and ICOM (Curricula Guidelines for Museum Professional Development).

5. As this article was going to press d'Harnoncourt passed away; her successor had not yet been named. 
6. Montebello announced his retirement in January 2008; at publication, his successor was not named.

7. Some of these Directors also hold the title of President or CEO.

8. As this article was going to press, Lane announced his retirement. His successor, Bonnie Pitman, worked in curating, directing, and administration in a number of nationally prestigious museums.

9. Some observers have spoken informally of a "Harvard Mafia" and "Williams Mafia", given the predominance of these schools' alumni amongst museum directors.

10. Alex Prud'homme. "The CEO of Culture Inc." Time 20 Jan. 1992

11. Rich served as President and CEO of LACMA until 1999, when she added Director to her title.

12. "Conflicting Visions in American Art Museums." Theory\&Society, vol. 10, No. 1, Jan. 1981: 103-25.

13. "Glenn Lowry Presented with Distinguished Alumni Award”, www.holderness.org, Feb. 2005.

14. The title of an article by Franklin W. Robinson in Museum News March/April 2001.

15. Richard A. Peterson: "The Role of Formal Accountability in the Shift from Impresario to Arts Administrator." Sociologie de l'Art, Colloque international Marseille 13-14 June 1985, la Documentation française, Paris, $1986: 112$.

16. Zolberg 110.

17. An excellent source on the history of the academic discipline of art history is the volume Craig Hugh Smyth \& Peter M. Lukehart, eds: The Early Years of Art History in the United States, Princeton University Department of Art and Archaeology, 1990.

18. Peterson 112 .

19. See Calvin Tompkins: Merchants \& Masterpieces 353.

20. Comment by James Gordon Bennett, publisher of the New York Herald, on the founders of the short-lived New-York Gallery of Fine Art; cited by Wallach in Exhibiting Contradiction: 17.

21. See "Princeton: The Beginnings" in The Early Years of Art History in the United States: 7-36.

22. Zolberg 112.

23. Walker. Self Portrait with Donors 150 . Walker's family had a fortune from iron ore and steel.

24. Figure cited by Janet Tassel. "Reverence for the object. Art museums in a changed world." Harvard Magazine, Sept-Oct. 2002, 48-58, 98-99; 49-50: 50.

25. See Walker, Warburg (op cit.), and Richard Feigen. Tales from the Art Crypt. New York: Random House, 2000.

26. Title of Tassel's article in Harvard magazine in 2002 for the 80th anniversary of Sachs' course. 27. To cite a few: directors of the Metropolitan (James Rorimer), of the Boston Museum of Fine Arts (Perry Rathbone and James Plaut, the latter of whom also was founding director of Boston's Institute ofContemporary Arts), the MoMA (Alfred H. Barr Jr.), the Wadsworth Atheneum in Hartford, Connecticut (A. Everett "Chick" Austin), the first Chief Curator and second Director of the National Gallery of Art (John Walker), and the founder of the New York City Ballet (Lincoln Kirstein).

28. Edward Warburg. "An Undergraduate's Experience of Fine Arts at Harvard in the 1920s." The Early Years of Art History in the United States. Ed. Smyth \& Lukehart: 44.

29. See e.g. Sybil Gordon Kantor, Alfred H. Barr: The Intellectual Origins of the MoMA, MIT, Cambridge \& London, 2002. Despite his devoted service, Barr clashed with the trustees over his tastes (seen as too radical and European). In 1943, the Board voted to have Barr fired-a clear conflict between businessmen and art historians. He held a less prestigious position in the library until 1949, when he was named Director of Collections, the title he held until retiring in 1967.

30. See Lauren Weiss Bricker, “American Backgrounds: Fiske Kimball's Study of Architecture in the United States." Smyth \& Lukehart.

31. A History of Architecture, with G. H. Edgell (1918), Domestic Architecture of the American Colonies (1922), American Architecture (1928), and The Creation of the Rococo (1943). 
32. In 1965 the museum split into the LACMA and the Museum of Natural History.

33. In Edward P.Alexander, "Wilhelm Bode and Berlin's Museum Island," Museum Masters, Their Museums and Their Influence, American Association for State and Local History, Nashville, 1983; 205-238: 214.

34. "Custodian of the Attic." Time 29 Dec. 1952.

35. As printed in the Herald Tribune 11 May 1939.

36. Faye Levine: The Culture Barons: An Analysis of Power and Money in the Arts, Thomas Crowell, New York, 1976, p. 148. Hoving's father was formerly CEO of luxury firm Tiffany's.

37. Brown's father had also been a student of Sachs (contemporaneously with Walker), and was descended from a long line of Rhode Island wealth for whom Brown University is named.

38. Peterson 114.

39. Walker 53.

40. He also served as New York Parks Commissioner, appointed by friend Mayor John V. Lindsay.

41. Tompkins, Merchants \& Masterpieces, New York, 1989, p. 353. After leaving the museum in 1977, Hoving launched a consulting group, Hoving Associates, and remained a public personality, as arts correspondent for the television show 20/20, editor of Connoisseur magazine, and author of general audience books, including Making the Mummies Dance (New York: Simon \& Schuster, 1993) and Art for Dummies (New York: Lifestyles, 1999).

42. National Gallery of Art, Field Museum of Natural History (Chicago), New Orleans Museum of Art, Los Angeles County Museum of Art, Seattle Art Museum, and the Metropolitan.

43. Francis Haskell: The Ephemeral Museum. Old Master Paintings and the Rise of the Art Exhibition. New Have: Yale University Press, 2000.

44. "J. Carter Brown Remembered for Blockbuster of a Life." OVATION-The Arts Network 18 July 2002.

45. Zolberg 119.

46. Figure provided bythe Association of Art Museum Directors.

47. "Smithsonian's Small Quits in Wake of Inquiry," Jacqueline Trescott and James V. Grimaldi, Washington Post 27 March 2007.

48. In James V. Grimaldi, “Portrait Cost Indian Museum \$48,500,” Washington Post 4 January 2008.

49. See "Getty director steps down." Art in America. Dec. 2004; Steve Lopez. "Munitz's Flight Plan Runs Into Head Wind." LA Times 31 Aug. 2005.

50. Janet Zink. “Tampa director faces a city's doubts.” St Petersburg Times 13 Feb. 2005.

51. Cited in Carol Vogel. "Director's Brief Stay at Dia Is Over." New York Times 1 March 2008.

52. Cited in Jacqueline Trescott. "Smithsonian Undersecretary for Art Ned Rifkin to Leave in April." Washington Post 13 March 2008.

53. Quoted in an interview with Deyan Sudjic. "There's steel in his soul." The Guardian 19 June 2005.

54. See Jennifer Donnelly \& Mathilde Gautier. "Commerce, culture et mondialisation: les expositions événementielles aux États-Unis et en France." Patrimoine et mondialisation. Paris: L'Harmattan, 2008.

55. Cited in Leah Arroyo. "What They Really Want to Do is Direct." Museum News Nov./Dec. 2007. 


\section{RÉSUMÉS}

This essay explores the evolving relationship between art historical expertise and business and administration skills amongst art museum directors in the United States. The first part assesses the profiles of current museum leaders through the lens of "art" and "business" responsibilities and knowledge. The second part studies the development of the profession in the United States in order to place today's trends into a broader historical context. The juxtaposition of contemporary and historical examples is meant to help analyze the tensions between the realms of art history and of business in American museums as they continue to redefine their role as not-for-profit cultural institutions responsible for their own financial soundness.

INDEX

Keywords : Arts Administration, Art Museum Directors, Commercialization, Cultural Management, Museum History

\section{AUTEUR}

\section{JENNIFER A. DONNELLY}

University Paris 7 